\title{
Mizah Tarzlarının Özgüven ve Özsaygı Düzeyine Etkisi: Üniversite Öğrencileri Üzerine Bir Araştırma
}

\author{
Altan AYAN*
}

Mizah Tarzlarının Özgüven ve Özsaygı Düzeyine Etkisi: Üniversite Öğrencileri Üzerine Bir Araştırma

\section{Özet}

Araştırmada ilk olarak mizah tarzları, özgüven ve özsaygı kavramları açıklanmıştır. Daha sonra mizah tarzlarının özgüven ve özsaygı düzeyi üzerine etkisi araştırımıştır. Araştırma kapsamında frekans analizi, faktör analizi, güvenirlik testi, çoklu regresyon testleri uygulanmış ve değişkenlere ilişkin ortalamalar hesaplanmıştır. Araştırmanın amacı mizah tarzlarının özgüven ve özsaygı düzeyi üzerine etkisini incelemektir. Çalışmanın örneklemi bir devlet üniversitesinin uygulamalı bilimler yüksekokulundaki 334 öğrencidir. Çalışmada sonuç olarak kendine yararlı mizah ve sosyal mizahın hem iç özgüven düzeyini hem dış özgüveni hem de kendine olumlu bakış düzeyini arttırdığı görülmüştür. Kendine yararlı mizah ve sosyal mizahın özgüven ve özsaygıyı arttıran önemli mizah tarzları olduğu söylenebilir. Sonuç olarak sosyal mizahın kendine olumsuz bakış seviyesini azalttığı görülmüştür.

Anahtar Kelimeler: Mizah, Mizah Tarzları, Özgüven, Özsaygı
The Effect of Humor Styles on the Level of SelfConfidence and Self-Esteem: A Research on University Students

\section{Abstract}

In the study, firstly, the concepts of humor styles, selfconfidence and self-esteem are explained. Secondly, it was investigated whether the humor styles affect the level of selfconfidence and self-esteem. Within the scope of the research, frequency analysis, factor analysis, reliability test, multiple regression tests were applied and the mean values of the variables were calculated. The purpose of the study is to examine the effect of humor styles on the level of self-confidence and self-esteem. The sample of the study is a total of 334 students in the Applied Sciences School of a state university. The results of the study showed that self-developing humor and social humor increase both the level of internal self-confidence and external self-confidence, along with the level of self-positive attitude. It can be said that self-developing humor and social humor are important humor styles that increase self-confidence and selfesteem. Consequently, it has been seen that social humor decreases the level of negative self-view.

Key Words: Humor, Humor Styles, Self-Confidence, Self-Esteem

\section{Giriş}

Özgüven ve özsaygı kişiler için çok önemli kavramlardır. Özgüven ve özsaygı düzeyi yüksek kişilerin daha başarı ve sosyal kişiler olduğu düşünülebilir. Mizah ve mizah tarzları da olumlu kullanıldığında bireylere sosyallik ve katkı sağlayabilir. Özgüven ve özsaygı düzeyi üzerine mizah tarzlarının

\footnotetext{
*Altan AYAN, Dr.Öğr.Üyesi., Trakya Üniversitesi, Uzunköprü Uygulamalı Bilimler Yüksekokulu, Halkla iliş̧kiler ve Reklamcılık Bölümü, altanayan@trakya.edu.tr; ORCID ID orcid.org / 0000-0002-3667-6577
} 
etkisinin incelenmesi bu açıdan önemlidir. Araştırmada mizah tarzlarının özgüven ve özsaygı düzeyini ne şekilde etkilediği incelenmiştir. Bu kapsamda üniversite öğrencilerine yönelik bir araştırma gerçekleştirilmiştir. Kişilerin yüksek özgüven ve yüksek özsaygıya sahip olmasının başarıları için çok önemli olduğu söylenebilir. Aynı zamanda yüksek özgüven ve özsaygıya sahip kişilerin çevreleri ile iletişimlerini daha kolay sürdürebilecekleri ve daha sosyal olabilecekleri düşünülebilir. Bu açıdan üniversite öğrencilerinin mizah tarzlarının özgüven ve özsaygı üzerine etkilerinin incelenmesinin önemi ortaya çıkmaktadır. Çalışmada öncelikle mizah tarzlarının özgüven düzeyi üzerine etkisi incelenmiştir. Daha sonra mizah tarzlarının özsaygı düzeyi üzerine etkisi araştırılmıştır. Son olarak özgüven düzeyinin özsaygı üzerine etki edip etmediği ele alınmıştır. Bu konuda gerçekleştirilen araştırmaların genellikle mizah tarzları ve özsaygı ilişkisini incelediği (Vaughan, Zeigler-Hill ve Arnau, 2014; Hiranandani ve Yue, 2014; Traş, Arslan ve Mentiş Taş, 2011; Zeigler-Hill ve Besser, 2011; Zhao, Kong ve Wang, 2012; Zhao, Wang ve Kong, 2014) söylenebilir. Literatürde mizah tarzlarının özgüven düzeyi üzerine etkisinin pek incelenmediği söylenebilir. Çalışmada mizah tarzlarının özgüven düzeyi üzerine etkisinin araştırımasının alana katkı sağladığı söylenebilir. Bu açıdan mizah tarzlarının hem iç özgüven hem de dış özgüven üzerine etkisinin araştırılması ve özgüven düzeyinin özsaygı üzerine etkisinin incelenmesi çalışmanın önemi ve katkısını ortaya koymaktadır.

\section{Kavramsal Çerçeve}

Mizah duygusuna sahip olmak bir kişilik özelliği olarak ifade edilebilir. Mizahın bileşenleri olarak mutluluk ve sağlık gibi olumlu kavramlar ile küçümseme ve alay etmek gibi olumsuz unsurlar görülebilir. Mizah kavramının çok boyutlu bir kavram olarak geliştiği söylenebilir. Mizah, stresli durumlarla karşılaşıldığında bir başa çıkma metodu olarak kullanılabilir (Aslan ve Çeçen, 2007, s.23). Mizah duygusu bireyin komik olan bir şeyi algılaması ve ifade edebilmesiyle ilgili iken, mizah anlayışı kişinin çevresindeki mizahi olayları görme becerisini içerir. Mizah üretebilme bireyin çeşitli durumlarda mizahi davranış ve faaliyet sergileyebilme eğilimi olarak açıklanabilir (Erözkan, 2009, s.57). Mizah kişinin kendisi ve başkalarına karşı olumlu kullanıldığında bireyler arası ilişkilerin iyi olması, kişinin kendini geliştirmesi ve zorluklarla mücadele edebilmesine katkı sağlar. Mizahın yıpratıcı olarak kullanıldığında özsaygıyı düşürdüğü, kaygı ve depresyon seviyesini arttırdığı ifade edilebilir (Özbay vd., 2012, s.327). Mizahın psikolojik ve fiziksel sağlık açısından yararlı olduğu, gerginliği düşürdüğü ve bu sayede yaşam kalitesini arttırdığı söylenebilir. Mizah genellikle kaygı ve stres duygularını düşürürken, özsaygı ve iyimserlik duygularını arttırabilir. Bireyler arası bir mizah tarzı olan katıımcı mizaha sahip kişilerin özsaygı düzeylerinin yüksek olduğu ifade edilebilir (Reisoğlu ve Yazıcl, 2017, s.891).

Katılımcı mizah sosyal ilişkileri kolaylaştııı ı mizah tarzı olarak açıklanabilir. Kendini geliştirici mizah, stresli durumlarla karşılaşıldığında mizahi bakış açısını sürdürebilme yeteneğini içerir. Saldırgan mizah tarzı başkalarına gülmek ve alay konusu yapmakla ilgili iken, kendini yıkıc mizah kişilerin başkalarının gözüne girmek için kendilerini kötülemesini içerir (Martin vd., 2012, s.178). Katılımcı mizah ve kendini geliştirici mizah olumlu tarzlar iken, saldırgan mizah ve kendini yıkıcı mizah olumsuz tarzlar olarak karakterize edilen değişkenlerdir. Olumlu tarzlar olan katılımcı mizah ve kendini 
geliştirici mizahın genellikle depresyon ve kaygı ile negatif yönlü, özsaygı ile pozitif yönlü bir ilişkiye sahip olduğu söylenebilir (Galloway, 2010, s.563). Katılımcı mizah bireyler arasındaki iletişimi kolaylaştıran dostça mizahi konuşma ve şakaları içerir. Kendini geliştirici mizah yaşamın stres faktörlerine eğlenceli olarak bakabilme becerisi olarak açıklanabilir. Saldırgan mizah küçümsemeyi kapsar ve başkalarını inciterek ya da yönlendirerek denetim altına almayı içerir. Kendini yıkıcı mizah kişilerin başkalarını eğlendirmek için kendilerini aşıı bir biçimde kötüleyici şakalarını kapsar (Veselka vd., 2010, s.772).

Özgüven, bireyin yetilerinin bir amacı başarmasına izin vereceği ve kendisini başarısızlık ile başkaları tarafından negatif değerlendirilmenin zayıflatıcı sonuçlarına karşı koruyacağı düşüncesine dayanır. Bireyin kendi yeterliliğine inancı olası bir eleştiri ya da aşağılanma durumunda sarsılabilir (Beck ve Emery, 2015, s.139-140). Özgüven sahibi kişiler yeteneklerine güvenir, yaşamlarını kontrol edebilir, kendilerine inanır ve sağduyulu bir biçimde planlar yaparlar. Özgüvenin bireyin sadece kişisel yetenekleri değil, aynı zamanda başka kişilerle kurduğu ilişkilerle yakından ilgili olduğu söylenebilir. Özgüven bireyin kendi yeteneklerine, becerilerine, bilgisine, beden diline, motivasyonuna, düşüncelerine ve zekasına güvenmesi olarak açıklanabilir. Özsaygı ile güven duygusu farklı kavramlardır. Özsaygı kavramı ilişkileri, özgüven seviyesini, kariyer seçimini, mutluluğu ve başarıları içerir. Kişiler bazı faaliyetleri uygulamada kendisine güvenebilir ancak özsaygısı düşük olabilir (Karadoğan Doruk, 2005, s.259-260). Özgüven kavramı bireyin kendine yönelik ve çevresi temelinde düşünceleri ile ilgilidir. Bu açıdan özgüven kavramı kişilerin kendilerine yönelik görüşlerini oluştururken başkalarının düşüncelerini de dikkate alabileceğini içerir (Maclellan, 2014, s.62). Düşük özgüvene sahip kişiler kendilerini önemsiz olarak görebilir, depresyon ve kaygı gibi sorunlarla karşılaşabilir. Yüksek özgüveni olan kişiler kendilerine yönelik olumlu düşüncelere sahiptir, stresle başa çıkma ve uyum düzeyleri yüksektir (Karacan Özdemir, 2016, s.137).

Özsaygı kavramı kişinin kendisine yönelik ayrıntıı değerlendirmelerini nasıl tanımladığı ile ilgilidir. Özsaygının psikoloji araştırmalarında odaklanılan ve psikoloji biliminin başlangııından itibaren incelenen bir kavram olduğu söylenebilir (Maroiu, Maricutoiu ve Sava, 2016, s.235). Özsaygısı yüksek bireyler başarısızlık karşısında ısrarcı, duygusal olarak istikrarlı, daha az esnek, ikna edilmeleri daha zor ve tutarlı bir benlik kavramına sahiptirler. Özsaygısı düşük bireyler günlük olayların etkisine kolay kapılan, esnek, kolay etki altında kalan, tutarsız bir benlik kavramına sahip kişilerdir (Hogg ve Vaughan, 2007, s.162). Özsaygı bireyin kendine saygısı, kendini benimseyerek değer vermesi, değerli görmesi ve kendini nasıl değerlendirdiği ile ilgilidir. Özsaygı düşük ve yüksek özsaygı olarak ifade edilebilir. Yüksek özsaygıya sahip kişiler kendini olumlu görür ve iyi hissederler. Düşük özsaygıya sahip kişiler ise sıkılgan ve kendine güvenleri düşüktür. Özsaygı kişilerin sosyal yaşamlarını da etkileyebilir. Düşük özsaygı düzeyine sahip kişi sağlık sorunları ve yalnızlık ile karşılaşabilir (Reisoğlu, Gedik ve Göktaş, 2013, s.153). Özsaygı bireyin kendine ve kendi becerilerine yönelik olumlu bakışını içerir. Özsaygının hem sosyal davranışlarla hem de akademik başarı ile ilgili bir kavram olduğu söylenebilir. Yüksek özsaygı zihinsel, duygusal ve sosyal açıdan pozitif yönde bir gelişimi içerir (Akkuş Çutuk, 2017, s.506). 
Vaughan, Zeigler-Hill ve Arnau (2014) üniversite öğrencilerinin mizah tarzları ve özsaygıları düzeyleri arasındaki ilişkiyi araştırmış ve özsaygısı yüksek kişilerin katılımcı mizah tarzının yüksek, saldırgan mizah tarzının düşük ve kendini yıkıcı mizah tarzının düşük olduğunu ifade etmişlerdir. Hiranandani ve Yue (2014) mizah tarzları ve özsaygı ilişkisini üniversite öğrencilerine yönelik olarak incelemiş ve düşük özsaygısı olan kişilerin kendini yıkıcı mizah tarzlarının yüksek olduğunu belirtmişlerdir. Hiranandani ve Yue (2014) öğrencilerin en fazla katılımcı ve kendini geliştirici mizaha sahip olduklarını belirtmiş, özsaygının katıımc mizah ve kendini geliştirici mizah ile pozitif yönlü ilişkiye sahip olduğunu ifade etmişlerdir. Traş, Arslan ve Mentiş Taş (2011) eğitim fakültesi öğrencilerine yönelik mizah tarzları, problem çözme ve benlik saygısı üzerine bir araştırma gerçekleştirmiş, özsaygının katılımcı mizah ve kendini geliştirici mizah ile pozitif yönlü bir ilişkiye sahip olduğunu belirtmişlerdir. Traş, Arslan ve Mentiş Taş (2011) özsaygının saldırgan mizah ve kendini yıkıcı mizah ile negatif yönlü bir ilişkiye sahip olduğunu belirtmişlerdir.

Zeigler-Hill ve Besser (2011) üniversite öğrencilerine yönelik gerçekleştirdikleri araştırmalarında özsaygı düzeyinin katıımcı mizah ve kendini geliştirici mizah ile pozitif yönlü bir korelasyona sahip olduğunu belirtmişlerdir. Zeigler-Hill ve Besser (2011) özsaygı seviyesinin saldırgan mizah ve kendini yıkıcı mizah ile negatif yönlü bir korelasyona sahip olduğunu belirtmişlerdir. Zhao, Kong ve Wang (2012), kolej öğrencilerine yönelik gerçekleştirdikleri araştırmalarında kendini geliştirici mizah düzeyinin özsaygı üzerine pozitif yönlü anlamlı bir etkisinin olduğunu ifade etmişlerdir. Zhao, Kong ve Wang (2012) araştırmalarında özsaygının kendini geliştirici mizah ve katılımcı mizah ile pozitif yönlü, kendini yıkıcı mizah ve saldırgan mizah ile negatif yönlü bir korelasyona sahip olduğunu ifade etmişlerdir. Zhao, Wang ve Kong (2014), üniversite öğrencilerine yönelik çalışmalarında katıımcı mizah ve kendini geliştirici mizahın özsaygı üzerine pozitif yönlü bir etkisinin olduğunu ifade etmişlerdir. Zhao, Wang ve Kong (2014), özsaygının katılımcı mizah ve kendini geliştirici mizah ile pozitif, saldırgan mizah ve kendini yıkıc mizah ile negatif ilişkisi olduğunu belirtmişlerdir. Bu çerçevede çalışmada aşağıdaki hipotezler ve bu hipotezlere bağlı alt hipotezler oluşturulmuştur:

$\mathrm{H}_{1}$ :Mizah Tarzlarının İç Özgüven Düzeyi üzerine etkisi vardır.

$\mathrm{H}_{1 a}:$ Kendine Yararlı Mizahın İç Özgüven düzeyi üzerine etkisi vardır.

$\mathrm{H}_{1 b}$ :Sosyal Mizahın İç Özgüven düzeyi üzerine etkisi vardır.

$\mathrm{H}_{1 c}:$ Kendine Zararlı Mizahın İç Özgüven düzeyi üzerine etkisi vardır.

$\mathrm{H}_{1 d}$ :Saldırgan Mizahın İç Özgüven düzeyi üzerine etkisi vardır.

$\mathrm{H}_{2}$ :Mizah Tarzlarının Dış Özgüven Düzeyi üzerine etkisi vardır.

$\mathrm{H}_{2 a}$ : Kendine Yararlı Mizahın Dış Özgüven düzeyi üzerine etkisi vardır.

$\mathrm{H}_{2 b}$ : Sosyal Mizahın Dış Özgüven düzeyi üzerine etkisi vardır.

$\mathrm{H}_{2 c}$ : Kendine Zararıı Mizahın Dış Özgüven düzeyi üzerine etkisi vardır. 
$\mathrm{H}_{2 d}$ :Saldırgan Mizahın Dış Özgüven düzeyi üzerine etkisi vardır.

$\mathrm{H}_{3}$ :Mizah Tarzlarının Kendine Olumlu Bakış düzeyi üzerine etkisi vardır.

$\mathrm{H}_{3 a}$ : Kendine Yararlı Mizahın Kendine Olumlu Bakış düzeyi üzerine etkisi vardır.

$\mathrm{H}_{3 \mathrm{~b}}$ :Sosyal Mizahın Kendine Olumlu Bakış düzeyi üzerine etkisi vardır.

$\mathrm{H}_{3 c}$ : Kendine Zararlı Mizahın Kendine Olumlu Bakış düzeyi üzerine etkisi vardır.

$\mathrm{H}_{3 d}$ :Saldırgan Mizahın Kendine Olumlu Bakış düzeyi üzerine etkisi vardır.

$\mathrm{H}_{4}$ :Mizah Tarzlarının Kendine Olumsuz Bakış düzeyi üzerine etkisi vardır.

$\mathrm{H}_{4 a}$ : Kendine Yararlı Mizahın Kendine Olumsuz Bakış düzeyi üzerine etkisi vardır.

$\mathrm{H}_{4 b}$ :Sosyal Mizahın Kendine Olumsuz Bakış düzeyi üzerine etkisi vardır.

$\mathrm{H}_{4 c}$ : Kendine Zararılı Mizahın Kendine Olumsuz Bakış düzeyi üzerine etkisi vardır.

$\mathrm{H}_{4 d}$ :Saldırgan Mizahın Kendine Olumsuz Bakış düzeyi üzerine etkisi vardır.

$\mathrm{H}_{5}$ : Özgüven Düzeyinin Kendine Olumlu Bakış üzerine etkisi vardır.

$\mathrm{H}_{5 a}$ : İç Özgüvenin Kendine Olumlu Bakış üzerine etkisi vardır.

$\mathrm{H}_{5 b}$ : Dış Özgüvenin Kendine Olumlu Bakışüzerine etkisi vardır.

$\mathrm{H}_{6}$ : Özgüven Düzeyinin Kendine Olumsuz Bakış üzerine etkisi vardır.

$\mathrm{H}_{6 a}$ : İç Özgüvenin Kendine Olumsuz Bakış üzerine etkisi vardır.

$\mathrm{H}_{6 b}$ : Dış Özgüvenin Kendine Olumsuz Bakış üzerine etkisi vardır.

\section{Araştırma}

\subsection{Araştırmanın Amacı, Evren ve Örneklem}

Araştırmanın amacı, üniversite öğrencilerinin mizah tarzlarının özgüven ve özsaygı düzeyleri üzerine etkisini incelemektir. Öğrencilerin özgüven düzeylerinin özsaygıları üzerine etkisi de incelenmiştir. Çalışmanın örneklemi bir devlet üniversitesinin uygulamalı bilimler yüksekokulundaki 334 öğrencidir. Çalışmada bir devlet üniversitesine bağıı bir uygulamalı bilimler yüksekokulundaki öğrencilerden veriler toplanmıştır. Çalışmanın evreni bu devlet üniversitesinin tüm öğrencileridir.

\subsection{Araştırmada Kullanılan Ölçekler, Geri Dönüş Oranı ve Sınılılıklar}

Araştırmada mizah tarzlarını ölçmeye yönelik olarak 32 soruluk bir ölçek kullanılmıştır. Mizah tarzları ölçeği Martin vd. (2003) tarafından geliştirilen ve Yerlikaya (2003) tarafından geçerlik ve güvenirlik çalışmaları yapılan 32 soruluk bir ölçektir. Mizah tarzları ölçeğinde soru 1, 7, 9, 15, 16, 17, $22,23,25,29$ ve 31 ters puanlanmıştır. Yerlikaya (2003) mizah tarzları ölçeği alt boyutlarını "Kendi- 
ni Geliştirici Mizah", "Katılımcı Mizah", "Kendini Yıkıcı Mizah” ve "Saldırgan Mizah” olarak ifade etmiştir.

Araştırmada Akın (2007) tarafından geliştirilen 33 soruluk Özgüven ölçeği kullanılmıştır. Akın (2007) tarafından özgüven ölçeği, kişilerin kendilerine yönelik özgüvenini içeren "iç özgüven" ve kişilerin dış çevre ve sosyal yaşamlarına yönelik özgüvenini içeren "dış özgüven" olarak iki boyutlu ifade edilmiştir. 33 soruluk özgüven ölçeği Okyay (2012) çalışmasından alınmıştır. Akın (2015) özgüven ölçeğinde 17 sorunun iç özgüveni, 16 sorunun dış özgüveni ölçtüğünü ifade etmiştir. Akın (2015) özgüven ölçeğinde ters puanlanan madde olmadığını ifade etmiştir.

Çalışmada özsaygı düzeyini belirlemek için 10 soruluk Rosenberg Özsaygı Ölçeği kullanıımıştır. Özsaygı ölçeği Rosenberg (1965) tarafından geliştirilmiştir. Rosenberg özsaygı ölçeğinde 5 olumlu ve 5 olumsuz soru bulunmaktadır. Rosenberg özsaygı ölçeği Çuhadaroğlu (1986) tarafından Türkçe'ye uyarlanmıştır.

Çalışmada kullanılan mizah tarzları ölçeği, özgüven ölçeği ve özsaygı ölçeği için beşli Likert puanlama yapılmıştır. Araştırma kapsamında cinsiyet, yaş, sınıf, baba eğitim durumu, anne eğitim durumu, kardeş sayısı, kaldığı yer, yetişme çağında bulunduğu yer ile ilgili sosyo-demografik özelliklere yönelik sorulara yer verilmiştir. Çalışma kapsamında toplam 350 anket dağıtılmıştır. Dağıtılan anketlerden 334 tanesi tam olarak doldurulmuştur. Geri dönüş oranının \%95 olduğu ifade edilebilir. Araştırmanın sınırıııkları sadece bir üniversite ve sadece bir yüksekokuldaki öğrencilerin çalışma kapsamına alınmasıdır.

\subsection{Araştırma Modeli}

Araştırma modeli mizah tarzları, özgüven düzeyi ve özsaygı düzeyi değişkenleri temel alınarak oluşturulmuştur. Model kapsamında öncelikle mizah tarzlarının özgüven üzerine etkisi ele alınmış ve iki çoklu regresyon modeli test edilmiştir $\left(\mathrm{H}_{1}\right.$ ve $\left.\mathrm{H}_{2}\right)$. Mizah tarzları alt boyutlarının iç özgüven düzeyi ve dış özgüven düzeyi üzerine etkisine ilişkin iki çoklu regresyon testi gerçekleştirilmiştir. Model kapsamında ikinci olarak mizah tarzlarının özsaygı düzeyi üzerine etkisi ele alınmış ve iki çoklu regresyon modeli sınanmıştır $\left(\mathrm{H}_{3}\right.$ ve $\left.\mathrm{H}_{4}\right)$. Mizah tarzları alt boyutlarının kendine olumlu bakış düzeyi ve kendine olumsuz bakış düzeyi üzerine etkisine ilişkin iki çoklu regresyon testi gerçekleştirilmiştir. Modelde son olarak özgüven düzeyinin özsaygı düzeyi üzerine etkisi incelenmiş ve iki çoklu regresyon modeli test edilmiştir $\left(\mathrm{H}_{5}\right.$ ve $\left.\mathrm{H}_{6}\right)$. Özgüven düzeyi alt boyutlarının kendine olumlu bakış düzeyi ve kendine olumsuz bakış düzeyi üzerine etkisine ilişkin iki çoklu regresyon testi gerçekleştirilmiştir. 
Şekil 1. Araştırma Modeli

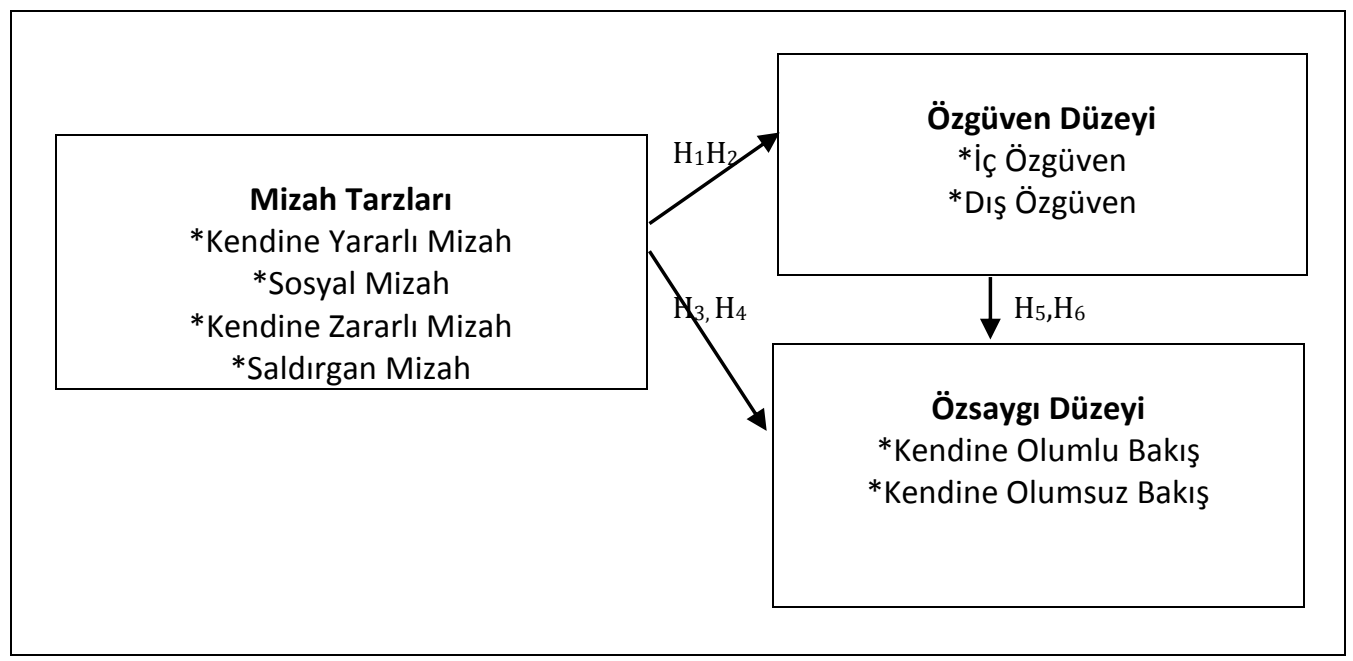

4. Veri Analizi

\subsection{Frekans Analizi}

Aşağıda Tablo 1'de katılımcıların sosyo-demografik özelliklerine ilişkin frekans dağııımları yer almaktadır.

Tablo 1. Sosyo-Demografik Özelliklere Yönelik Frekans Dağılımı

\begin{tabular}{|c|c|c|c|}
\hline Değişkenler & Gruplar & Frekans & Yüzde \\
\hline \multirow[t]{2}{*}{ Cinsiyet } & Erkek & 130 & 38,9 \\
\hline & Bayan & 204 & 61,1 \\
\hline \multirow[t]{4}{*}{ Yaş } & $18-19$ & 85 & 25,4 \\
\hline & $20-21$ & 191 & 57,2 \\
\hline & $22-23$ & 48 & 14,4 \\
\hline & 24 ve üzeri & 10 & 3,0 \\
\hline \multirow[t]{4}{*}{ SInIf } & 1.sınıf & 123 & 36,8 \\
\hline & 2.sinif & 143 & 42,8 \\
\hline & 3.sinıf & 31 & 9,3 \\
\hline & 4.sınıf & 37 & 11,1 \\
\hline
\end{tabular}




\begin{tabular}{|c|c|c|c|}
\hline \multirow[t]{5}{*}{ Baba Eğitim Durumu } & illk-orta & 213 & 63,8 \\
\hline & Lise & 87 & 26,0 \\
\hline & MYO & 9 & 2,7 \\
\hline & Lisans & 21 & 6,3 \\
\hline & Lisansüstü & 4 & 1,2 \\
\hline \multirow[t]{5}{*}{ Anne Eğitim Durumu } & İlk-orta & 263 & 78,7 \\
\hline & Lise & 57 & 17,1 \\
\hline & MYO & 4 & 1,2 \\
\hline & Lisans & 6 & 1,8 \\
\hline & Lisansüstü & 4 & 1,2 \\
\hline \multirow[t]{4}{*}{$\underline{\text { Kardeş Sayısı }}$} & 1 kardeş & 26 & 7,8 \\
\hline & 2 kardeş & 143 & 42,8 \\
\hline & 3 kardeş & 100 & 29,9 \\
\hline & 4 ve üzeri kardeş & 65 & 19,5 \\
\hline \multirow[t]{4}{*}{ Kaldığı Yer } & Ailenin Yanında & 35 & 10,5 \\
\hline & Yurtta & 224 & 67 \\
\hline & Akrabanın Yanında & 3 & 0,9 \\
\hline & Arkadaşlarıyla Birlikte & 72 & 21,6 \\
\hline Çağında & Köy & 53 & 15,9 \\
\hline \multirow[t]{4}{*}{ Bulunduğu Yer } & Belde & 10 & 3,0 \\
\hline & İlçe & 108 & 32,3 \\
\hline & il & 45 & 13,5 \\
\hline & Büyükşehir & 118 & 35,3 \\
\hline
\end{tabular}

\subsection{Faktör Analizi ve Güvenirlik Testleri}

Araştırmada kullanılan ölçeklere faktör analizi ve güvenirlik testleri gerçekleştirilmiştir. Öncelikle 32 soruluk mizah tarzları ölçeğine faktör analizi ve güvenirlik testi uygulanmıştır. Tablo 2'de sonuçlar verilmiştir. Mizah tarzları ölçeğine faktör analizi uygulanırken soru 7 ve soru 26 analizden çıkarılmıştır. Mizah tarzları ölçeği için soru 1, 7, 9, 15, 16, 17, 22, 23, 25, 29 ve 31 ters puanlanmıştır. 
Mizah tarzları ölçeği için KMO değerinin 0,763 ve Bartlett's testi sonucunun 0,000 olduğu belirtilebilir.

Araştırmalarda gözlem sayısının 250 olduğu durumda faktör ağırlıkları 0,35 olmalı iken, gözlem sayısının 350 ve üstü olduğu durumlarda ise faktör ağırlıkları 0,30 olmalıdır (Alpar, 2011, s.283). Bu araştırma 334 kişiye uygulanmıştır ve faktör ağırlıklarının 0,35 ve üzeri olduğu görülmektedir.

Tablo 2. Mizah Tarzları Ölçeği Faktör Analizi ve Güvenirlik Testi Sonuçları

\begin{tabular}{|c|c|c|c|c|c|}
\hline & Sorular & $\begin{array}{c}\text { Faktör } \\
\text { Ağırlıkları }\end{array}$ & $\begin{array}{l}\text { Faktör Açık- } \\
\text { layıcılığı(\%) }\end{array}$ & $\begin{array}{c}\text { Başlangıç } \\
\text { Özdeğerleri }\end{array}$ & $\begin{array}{c}\text { Cronbach's } \\
\text { Alpha }\end{array}$ \\
\hline Faktör 1, & MZ2 & 0,660 & & & \\
\hline Kendine Yararlı & MZ6 & 0,621 & & 3,881 & 0,690 \\
\hline \multirow[t]{5}{*}{ Mizah } & MZ18 & 0,619 & 10,349 & & \\
\hline & MZ10 & 0,564 & & & \\
\hline & MZ14 & 0,564 & & & \\
\hline & MZ30 & 0,444 & & & \\
\hline & MZ28 & 0,392 & & & \\
\hline Faktör 2, & MZ9 & 0,677 & & & \\
\hline \multirow[t]{6}{*}{ Sosyal Mizah } & MZ17 & 0,638 & 9,842 & 3,444 & 0,714 \\
\hline & MZ25 & 0,632 & & & \\
\hline & MZ29 & 0,593 & & & \\
\hline & MZ21 & 0,491 & & & \\
\hline & MZ13 & 0,486 & & & \\
\hline & MZ1 & 0,431 & & & \\
\hline Faktör 3, & MZ32 & 0,594 & & & \\
\hline Kendine Zararlı & MZ24 & 0,559 & & & \\
\hline \multirow[t]{8}{*}{ Mizah } & MZ12 & 0,519 & 9,263 & 2,259 & 0,694 \\
\hline & MZ19 & 0,512 & & & \\
\hline & MZ20 & 0,509 & & & \\
\hline & MZ8 & 0,503 & & & \\
\hline & MZ4 & 0,404 & & & \\
\hline & MZ16 & 0,402 & & & \\
\hline & MZ3 & 0,386 & & & \\
\hline & MZ5 & 0,353 & & & \\
\hline Faktör 4, & MZ31 & 0,652 & & & \\
\hline \multirow[t]{5}{*}{ Saldırgan Mizah } & MZ23 & 0,560 & & & \\
\hline & MZ11 & 0,458 & 7,423 & 1,479 & 0,527 \\
\hline & MZ15 & 0,421 & & & \\
\hline & MZ27 & 0,419 & & & \\
\hline & MZ22 & 0,411 & & & \\
\hline
\end{tabular}

KMO Değeri: 0,763; Bartlett's Testi Sonucu:0,000; Açıklanan Toplam Varyans: 36,877 
Mizah tarzları ölçeğine faktör analizi uygulanması neticesinde literatüre benzer dört alt boyut bulunmuştur. Bu boyutlardan faktör 1 "Kendine Yararlı Mizah", faktör 2 "Sosyal Mizah", faktör 3 "Kendine Zararlı Mizah" ve faktör 4 "Saldırgan Mizah" olarak adlandırımıştır. Kendine Yararı Mizah boyutu toplam varyansın \%10,349'unu, Sosyal mizah boyutu toplam varyansın \%9,842'sini, Kendine Zararlı mizah boyutu toplam varyansın \%9,263'ünü ve Saldırgan mizah boyutu toplam varyansın \%7,423'ünü açıkladığı ifade edilebilir. Bu dört alt boyut toplam varyansın \%36,877'sini açıklamaktadır. Başlangıç özdeğeri faktör 1 için 3,881, faktör 2 için 3,444, faktör 3 için 2,259 ve faktör 4 için 1,479 olarak belirlenmiştir. Cronbach's Alpha değeri Kendine yararlı mizah boyutu için 0,690, Sosyal mizah boyutu için 0,714, Kendine zararlı mizah boyutu için 0,694 olarak ve Saldırgan mizah boyutu için 0,527 olarak bulunmuştur.

33 soruluk özgüven ölçeğine faktör analizi ve güvenirlik testi uygulanmıştır. Tablo 3’te sonuçlar verilmiştir. Özgüven ölçeği için KMO değerinin 0,936 ve Bartlett's testi sonucunun 0,000 olduğu belirtilebilir.

Tablo 3. Özgüven Ölçeği Faktör Analizi ve Güvenirlik Testi Sonuçları

\begin{tabular}{|c|c|c|c|c|c|}
\hline & Sorular & $\begin{array}{l}\text { Faktör } \\
\text { Ağırlıkları }\end{array}$ & $\begin{array}{l}\text { Faktör Açık- } \\
\text { layıcılığı(\%) }\end{array}$ & $\begin{array}{l}\text { Başlangıç } \\
\text { Özdeğerleri }\end{array}$ & $\begin{array}{l}\text { Cronbach's } \\
\text { Alpha }\end{array}$ \\
\hline \multirow{20}{*}{$\begin{array}{l}\text { Faktör 1, } \\
\text { İç Özgüven }\end{array}$} & ÖG9 & 0,715 & \multirow{20}{*}{22,973} & \multirow{20}{*}{12,151} & \multirow{20}{*}{0,921} \\
\hline & ÖG7 & 0,695 & & & \\
\hline & ÖG13 & 0,688 & & & \\
\hline & ÖG17 & 0,671 & & & \\
\hline & ÖG6 & 0,640 & & & \\
\hline & ÖG19 & 0,621 & & & \\
\hline & ÖG15 & 0,615 & & & \\
\hline & ÖG32 & 0,605 & & & \\
\hline & ÖG4 & 0,605 & & & \\
\hline & ÖG16 & 0,604 & & & \\
\hline & ÖG25 & 0,586 & & & \\
\hline & ÖG10 & 0,581 & & & \\
\hline & ÖG12 & 0,551 & & & \\
\hline & ÖG27 & 0,540 & & & \\
\hline & ÖG21 & 0,507 & & & \\
\hline & ÖG18 & 0,478 & & & \\
\hline & ÖG3 & 0,437 & & & \\
\hline & ÖG1 & 0,435 & & & \\
\hline & ÖG5 & 0,386 & & & \\
\hline & ÖG33 & 0,350 & & & \\
\hline
\end{tabular}




\begin{tabular}{lllll}
\hline & ÖG11 & 0,754 & & \\
Faktör 2, & ÖG31 & 0,741 & & \\
Diş Özgüven & ÖG28 & 0,723 & & \\
& ÖG24 & 0,672 & & \\
& ÖG26 & 0,667 & & \\
& ÖG8 & 0,658 & & \\
& ÖG14 & 0,598 & & \\
& ÖG29 & 0,591 & 1,861 & \\
& ÖG23 & 0,520 & & \\
& ÖG2 & 0,477 & & \\
& ÖG22 & 0,416 & & \\
& ÖG30 & 0,361 & & \\
ÖG20 & 0,346 & & \\
\hline
\end{tabular}

KMO Değeri: 0,936; Bartlett's Testi Sonucu:0,000; Açılanan Toplam Varyans: 42,462

Özgüven ölçeğine faktör analizi uygulanması neticesinde literatüre benzer iki alt boyut bulunmuştur. Bu boyutlardan faktör 1 “iç̧ Özgüven” olarak ve faktör 2 “Dış Özgüven” olarak isimlendirilmiştir. İç Özgüven boyutu toplam varyansın \%22,973’ünü ve Dış Özgüven boyutu toplam varyansın $\% 19,489$ 'unu açıklamaktadır. Bu iki alt boyut toplam varyansın \%42,462'sini açıklamaktadır. i̇ç Özgüven boyutu için başlangıç özdeğeri 12,151 iken, Dış Özgüven boyutu için başlangıç özdeğeri 1,861 olarak bulunmuştur. Güvenirlik testi sonucu Cronbach's Alpha değeri İç Özgüven boyutu için 0,921 olarak ve Dış Özgüven boyutu için 0,880 olarak bulunmuştur.

10 soruluk özsaygı ölçeğine faktör analizi ve güvenirlik testi uygulanmıştır. Aşağıda Tablo 4'te sonuçlar yer almaktadır. Özsaygı ölçeği için KMO değerinin 0,813 ve Bartlett's testi sonucunun 0,000 olduğu belirtilebilir.

Tablo 4. Özsaygı Ölçeği Faktör Analizi ve Güvenirlik Testi Sonuçları

\begin{tabular}{lccccc}
\hline \hline & Sorular & $\begin{array}{c}\text { Faktör } \\
\text { Ağırlıkları }\end{array}$ & $\begin{array}{c}\text { Faktör Açık- } \\
\text { layıcılığı(\%) }\end{array}$ & $\begin{array}{c}\text { Başlangıç } \\
\text { Özdeğerleri }\end{array}$ & $\begin{array}{c}\text { Cronbach's } \\
\text { Alpha }\end{array}$ \\
\hline Faktör 1, & SA2 & 0,842 & & & \\
Kendine & SA7 & 0,798 & & & \\
Olumlu Bakış & SA1 & 0,771 & 31,624 & 3,982 & 0,845 \\
& SA6 & 0,762 & & & \\
& SA4 & 0,692 & & & \\
\hline
\end{tabular}


Altan AYAN

\begin{tabular}{lccccc}
\hline & & & & & \\
Faktör 2, & SA9 & 0,873 & & \\
Kendine & SA10 & 0,784 & 29,296 & 2,110 & 0,806 \\
Olumsuz & SA5 & 0,775 & & & \\
Bakış & SA3 & 0,739 & & & \\
& SA8 & 0,513 & & & \\
\hline
\end{tabular}

KMO Değeri: 0,813; Bartlett's Testi Sonucu:0,000; Açıklanan Toplam Varyans: 60,920

Özsaygı ölçeğine faktör analizi uygulanması neticesinde literatüre uygun iki alt boyut bulunmuştur. Bu boyutlardan faktör 1 Kendine Olumlu Bakış ve faktör 2 Kendine Olumsuz Bakış olarak adlandırımıştır. Bunlardan Kendine Olumlu Bakış boyutu toplam varyansın \%31,624'ünü ve Kendine Olumsuz Bakış boyutu toplam varyansın \%29,296'sını açıklamaktadır. Bu iki alt boyut toplam varyansın \%60,920'sini açıklamaktadır. Faktör 1 için başlangıç özdeğeri 3,982 iken, faktör 2 için başlangıç özdeğeri 2,110 olarak belirlenmiştir. Güvenirlik testi sonucu bulunan Cronbach's Alpha değeri Kendine Olumlu Bakış boyutu için 0,845 iken, Kendine Olumsuz Bakış boyutu için 0,806 olarak bulunmuştur.

\section{3. Çoklu Regresyon Testleri}

\subsubsection{Mizah Tarzlarının Özgüven Üzerine Etkisi}

\subsubsection{Mizah Tarzlarının İç Özgüven Üzerine Etkisi}

Mizah tarzları alt boyutlarının iç özgüven düzeyi üzerine etkisi çoklu regresyon modeli ile test edilmiştir. Çoklu regresyon testi sonuçları aşağıda Tablo 5'te verilmiştir. Mizah tarzları ölçeği alt boyutları bağımsız değişken olarak, iç özgüven bağımlı değişken olarak incelenmiştir.

VIF değerinin 10'dan küçük olması ve tolerans değerlerinin 0,1'den büyük olması halinde çoklu bağıntı olmadığı ifade edilebilir (Çokluk, Şekercioğlu ve Büyüköztürk, 2012, s.35-36). Çoklu regresyon modelinde bağımsız değişken olan mizah tarzları ölçeği alt boyutlarına yönelik çoklu bağıntı olup olmadığı Tolerans ve VIF değerlerine bakarak incelenmiştir. En yüksek VIF değerinin 1,305 olduğu, en düşük tolerans değerinin 0,766 olduğu görülmüştür. VIF değerlerinin sınır değer olan 10'dan oldukça düşük olduğu ve Tolerans değerlerinin sınır değer olan 0,1'den oldukça yüksek olduğu görüldüğünden çoklu bağıntı sorunu olmadığı söylenebilir. 
Tablo 5. Mizah Tarzlarının İç Özgüven Üzerine Etkisine ilişkin Çoklu Regresyon Sonuçları

\begin{tabular}{|c|c|c|c|c|c|}
\hline Model & $\begin{array}{r}\text { St } \\
\text { Edilme } \\
\mathrm{B}\end{array}$ & $\begin{array}{l}\text { rdize } \\
\text { Katsayılar } \\
\text { Std. Hata }\end{array}$ & $\begin{array}{c}\text { Standardize } \\
\text { Edilmiş Katsayılar } \\
\text { Beta }\end{array}$ & $t$ & Sig. \\
\hline (Constant) & 2,952 & 0,240 & & 12,318 & 0,000 \\
\hline $\begin{array}{l}\text { Kendine } \\
\text { Yararlı Mizah }\end{array}$ & 0,287 & 0,047 & 0,339 & 6,143 & 0,000 \\
\hline Sosyal Mizah & 0,116 & 0,044 & 0,139 & 2,671 & 0,008 \\
\hline $\begin{array}{l}\text { Kendine } \\
\text { Zararlı Mizah }\end{array}$ & $-0,031$ & 0,054 & $-0,033$ & $-0,580$ & 0,562 \\
\hline Saldırgan Mizah & $-0,088$ & 0,048 & $-0,101$ & $-1,835$ & 0,067 \\
\hline
\end{tabular}

Bağımlı Değişken: İç Özgüven

$R=0,412 ; R^{2}=0,170$; Düzeltilmiş $R^{2}=0,160 ;$ Standart Hata $=0,55167$

$F=16,803 ; p=0,000$

Tablo 5 'te regresyon sonuçlarında görüldüğü gibi, kendine yararlı mizah düzeyinin iç özgüven üzerine pozitif yönlü anlamlı bir etkisi $(\beta=0,339)$ vardır $(p<0,05)$. $H_{1 a}$ desteklenmiştir. Kendine yararIı mizah iç özgüven düzeyini arttırmaktadır. Kendine yararlı mizahın olumlu bir mizah anlayışı olması bu sonuçla ilgili olabilir. Sosyal mizah düzeyinin iç özgüven üzerine pozitif yönlü anlamlı bir etkisi $(\beta=0,139)$ vardır $(p<0,05)$. $H_{1 b}$ desteklenmiştir. Sosyal mizah iç özgüven düzeyini arttırmaktadır. Sosyal mizahın iletişime yönelik bir mizah tarzı olması bu sonucu ortaya çıkarmış olabilir. Kendine yararlı mizahın iç özgüven üzerine etkisi $(\beta=0,339)$, sosyal mizahın iç özgüvene etkisinden $(\beta=0,139)$ daha yüksektir. Kendine yararlı mizahın sosyal mizaha göre iç özgüveni daha fazla arttırdığı söylenebilir. Kendine zararlı mizah ve saldırgan mizah düzeyinin iç özgüven üzerine anlamlı bir etkisi yoktur ( $p>0,05)$. $\mathrm{H}_{1 \mathrm{c}}$ ve $\mathrm{H}_{1 d}$ reddedilmiştir.

\subsubsection{Mizah Tarzlarının Dış Özgüven Üzerine Etkisi}

Mizah tarzları ölçeği alt boyutlarının dış özgüven düzeyi üzerine etkisine yönelik çoklu regresyon modeli test edilmiştir. Aşağıda Tablo 6'da çoklu regresyon testi sonuçları verilmiştir. Mizah tarzları ölçeği alt boyutları bağımsız değişken olarak, dış özgüven bağımlı değişken olarak incelenmiştir. 
Altan AYAN

Tablo 6. Mizah Tarzlarının Dış Özgüven Üzerine Etkisine Yönelik Çoklu Regresyon Sonuçları

\begin{tabular}{lccccc}
\hline \hline Model & \multicolumn{2}{c}{$\begin{array}{c}\text { Standardize } \\
\text { Edilmemiş Katsayılar }\end{array}$} & $\begin{array}{c}\text { Standardize } \\
\text { Edilmiş Katsayılar }\end{array}$ & $t$ & Sig. \\
& $\underline{\text { B }}$ & $\underline{\underline{\text { Std. }}}$ & $\underline{\text { Beta }}$ & & \\
& 1,867 & 0,267 & & 6,989 & 0,000 \\
\hline $\begin{array}{l}\text { (Constant) } \\
\text { Kendine Yararlı }\end{array}$ & 0,327 & 0,052 & 0,343 & 6,285 & 0,000 \\
$\begin{array}{l}\text { Mizah } \\
\text { Sosyal Mizah }\end{array}$ & 0,163 & 0,049 & 0,172 & 3,357 & 0,001 \\
Kendine Zararlı & 0,064 & 0,060 & 0,060 & 1,051 & 0,294 \\
Mizah & & & & & \\
Saldırgan Mizah & $-0,005$ & 0,053 & $-0,005$ & $-0,098$ & 0,922 \\
\hline
\end{tabular}

Bağımlı Değişken: Dış Özgüven

$R=0,435 ; R^{2}=0,189$; Düzeltilmiş $R^{2}=0,179 ;$ Standart Hata $=0,61492$

$F=19,087 ; p=0,000$

Tablo 6'da görüldüğü gibi, kendine yararlı mizah düzeyinin dış özgüven üzerine pozitif yönlü anlamlı etkisi $(\beta=0,343)$ mevcuttur $(p<0,05)$. $H_{2 a}$ desteklenmiştir. Kendine yararlı mizah dış özgüveni arttırmaktadır. Bu sonuç kendine yararlı mizahın kişinin mizahi bakış açısına yönelik olmasıyla ilgili olabilir. Sosyal mizah düzeyinin dış özgüven üzerine pozitif yönlü ve anlamlı bir etkisi $(\beta=0,172)$ mevcuttur $(p<0,05)$. $H_{2 b}$ desteklenmiştir. Sosyal mizah dış özgüveni arttırmaktadır. Sosyal mizahın sosyal ilişkilere yönelik mizah anlayışı olması bu sonuçla ilgili olabilir. Kendine yararlı mizah düzeyinin dış özgüvene etkisi $(\beta=0,343)$, sosyal mizah düzeyinin dış özgüvene etkisinden $(\beta=0,172)$ daha fazladır. Kendine yararlı mizahın sosyal mizaha göre dış özgüveni daha çok arttırdığı ifade edilebilir. Kendine zararlı mizah ve saldırgan mizah düzeyinin dış özgüven üzerine anlamlı bir etkisi yoktur ( $p>0,05)$. $\mathrm{H}_{2 c}$ ve $\mathrm{H}_{2 d}$ reddedilmiştir.

\subsubsection{Mizah Tarzlarının Özsaygı Üzerine Etkisi}

\subsubsection{Mizah Tarzlarının Kendine Olumlu Bakış Üzerine Etkisi}

Mizah tarzları ölçeği alt boyutlarının kendine olumlu bakış düzeyine etkisine ilişkin olarak çoklu regresyon modeli incelenmiştir. Aşağıda Tablo 7'de çoklu regresyon modeli sonuçları yer almaktadır. Mizah tarzları alt boyutları bağımsız değişken olarak, kendine olumlu bakış düzeyi bağımlı değişken olarak ele alınmıştır. 
Tablo 7. Mizah Tarzlarının Kendine Olumlu Bakış Üzerine Etkisine İlişkin Çoklu Regresyon Sonuçları

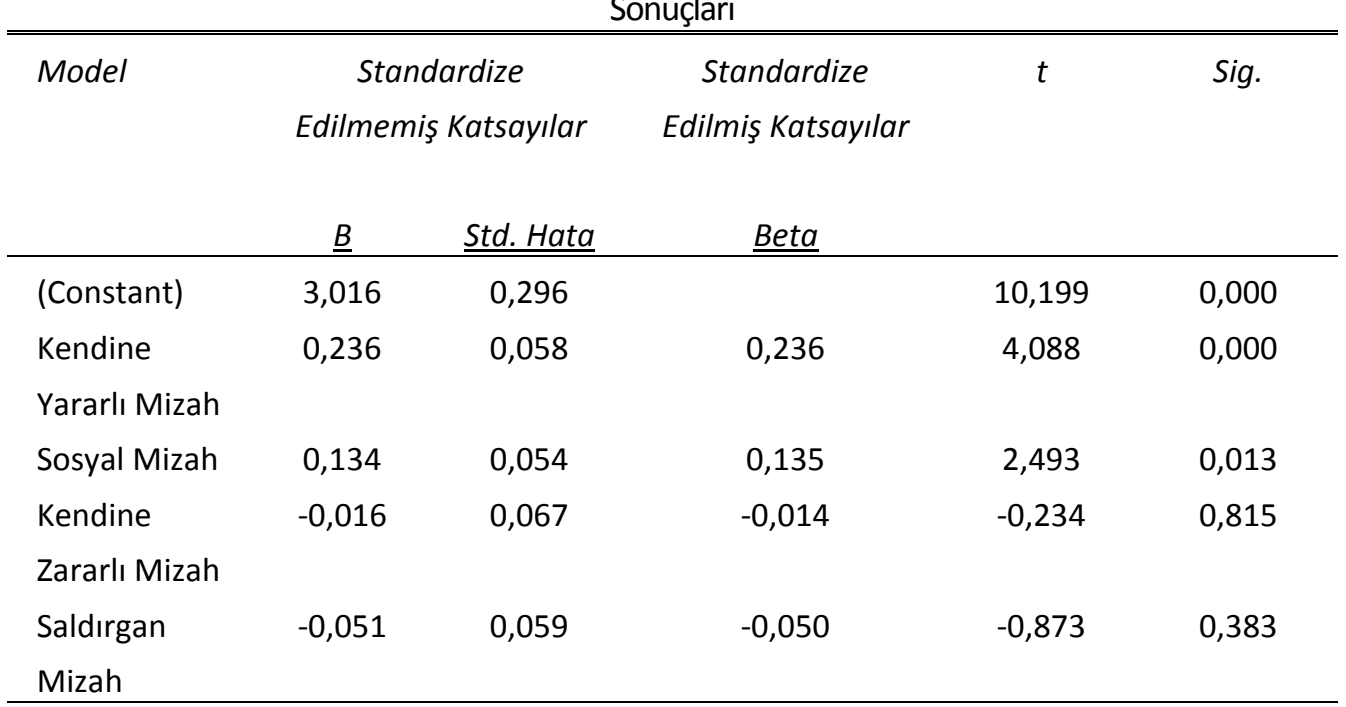

Bağımlı Değişken: Kendine Olumlu Bakış

$R=0,304 ; R^{2}=0,093$; Düzeltilmiş $R^{2}=0,081 ;$ Standart Hata $=0,68081$

$F=8,363 ; p=0,000$

Tablo 7'de çoklu regresyon sonuçlarında görüldüğü gibi, Kendine yararlı mizah düzeyinin kendine olumlu bakış düzeyi üzerine pozitif yönlü anlamlı bir etkisi $(\beta=0,236)$ vardır $(p<0,05)$. $\mathrm{H}_{3 a}$ desteklenmiştir. Kendine yararlı mizah kendine olumlu bakış düzeyini arttırmaktadır. Kendine yararlı mizahın kişilerin olumlu tutum ve davranışlarıyla ilgili olması bu sonucu ortaya çıkarmış olabilir. Sosyal mizah düzeyinin kendine olumlu bakış düzeyi üzerine pozitif yönlü anlamlı bir etkisi $(\beta=0,135)$ vardır $(p<0,05)$. $H_{3 b}$ desteklenmiştir. Sosyal mizah kendine olumlu bakışı arttırmaktadır. Bu sonuç sosyal mizahın kişileri geliştirici bir mizah tarzı olmasıyla ilgili olabilir. Kendine yararı mizahın kendine olumlu bakış üzerine etkisi $(\beta=0,236)$, sosyal mizahın etkisinden $(\beta=0,135)$ daha yüksektir. Kendine yararlı mizahın sosyal mizaha göre kendine olumlu bakış düzeyini daha çok arttırdığı ifade edilebilir. Kendine zararlı mizah ve saldırgan mizah düzeyinin kendine olumlu bakış düzeyi üzerine anlamlı bir etkisi yoktur $(\mathrm{p}>0,05)$. $\mathrm{H}_{3 c}$ ve $\mathrm{H}_{3 d}$ reddedilmiştir.

\subsubsection{Mizah Tarzlarının Kendine Olumsuz Bakış Üzerine Etkisi}

Mizah tarzları alt boyutlarının kendine olumsuz bakış düzeyi üzerine etki edip etmediği çoklu regresyon modeli ile incelenmiştir. Çoklu regresyon modeli sonuçları aşağıda Tablo 8'de verilmiştir. Mizah tarzları alt boyutları bağımsız değişken, kendine olumsuz bakış düzeyi bağımlı değişken olarak ele alınmıştır. 
Tablo 8. Mizah Tarzlarının Kendine Olumsuz Bakış Üzerine Etkisine Yönelik Çoklu Regresyon Sonuçları

\begin{tabular}{|c|c|c|c|c|c|}
\hline \multirow[t]{2}{*}{ Model } & \multicolumn{2}{|c|}{$\begin{array}{c}\text { Standardize } \\
\text { Edilmemiş Katsayılar }\end{array}$} & \multirow{2}{*}{$\begin{array}{c}\text { Standardize } \\
\text { Edilmiş Katsayılar } \\
\underline{\text { Beta }}\end{array}$} & \multirow[t]{2}{*}{$t$} & \multirow[t]{2}{*}{ Sig. } \\
\hline & $\underline{B}$ & Std. Hata & & & \\
\hline (Constant) & 3,069 & 0,415 & & 7,396 & 0,000 \\
\hline Kendine Yararlı & $-0,083$ & 0,081 & $-0,060$ & $-1,027$ & 0,305 \\
\hline \multicolumn{6}{|l|}{ Mizah } \\
\hline Sosyal Mizah & $-0,280$ & 0,075 & $-0,203$ & $-3,720$ & 0,000 \\
\hline Kendine Zararlı & 0,187 & 0,094 & 0,120 & 1,987 & 0,048 \\
\hline \multicolumn{6}{|l|}{ Mizah } \\
\hline Saldırgan Mizah & 0,118 & 0,083 & 0,083 & 1,424 & 0,155 \\
\hline
\end{tabular}

Bağımlı Değişken: Kendine Olumsuz Bakış

$R=0,283 ; R^{2}=0,080$; Düzeltilmiş $R^{2}=0,069 ;$ Standart Hata=0,95536

$F=7,123 ; p=0,000$

Tablo 8'de sosyal mizah düzeyinin kendine olumsuz bakış düzeyi üzerine negatif yönlü anlamlı bir etkisi $(\beta=-0,203)$ mevcuttur $(p<0,05)$. $\mathrm{H}_{4 b}$ desteklenmiştir. Sosyal mizah kendine olumsuz bakış düzeyini azaltmaktadır. Bu sonuç sosyal mizahın kişilerarası ilişkileri ve iletişimi geliştiren bir yaklaşım olmasından kaynaklanabilir. Kendine zararlı mizah düzeyinin kendine olumsuz bakış üzerine pozitif yönlü anlamlı bir etkisi $(\beta=0,120)$ mevcuttur $(p<0,05) . \mathrm{H}_{4 c}$ desteklenmiştir. Kendine zararlı mizah kendine olumsuz bakış düzeyini yükseltmektedir. Kendine zararlı mizahın olumsuz bir mizah tarzı olması bu sonuçla ilgili olabilir. Kendine yararlı mizah ve saldırgan mizah düzeylerinin kendine olumsuz bakış düzeyi üzerine anlamlı bir etkisi yoktur $(p>0,05) . \mathrm{H}_{4 a}$ ve $\mathrm{H}_{4 d}$ reddedilmiştir.

\subsection{3. Özgüven Düzeyinin Özsaygı Üzerine Etkisi}

\subsubsection{1. Özgüven Düzeyinin Kendine Olumlu Bakış Üzerine Etkisi}

Özgüven düzeyi alt boyutlarının kendine olumlu bakış düzeyi üzerine etki edip etmediği çoklu regresyon modeli ile incelenmiştir. Aşağıda Tablo 9'da çoklu regresyon testi sonuçları verilmiştir. Özgüven düzeyi alt boyutları bağımsız değişken olarak, kendine olumlu bakış düzeyi bağımlı değişken olarak değerlendirilmiştir.

Özgüven düzeyinin özsaygı üzerine etkisi incelenirken, özgüven düzeyi alt boyutları bağımsız değişken olarak incelenmiştir. Bağımsız değişken olan özgüven ölçeği alt boyutlarına yönelik çoklu bağıntı olup olmadığı Tolerans ve VIF değerleri incelenerek belirlenmiştir. En yüksek VIF değerinin 2,300 olduğu, en düşük tolerans değerinin 0,435 olduğu görülmüştür. VIF değeri sınır değer olan 
10'dan küçük ve Tolerans değeri sınır değer olan 0,1'den yüksek olduğundan çoklu bağıntı problemi olmadığı ifade edilebilir.

Tablo 9. Özgüven Düzeyi Alt Boyutlarının Kendine Olumlu Bakış Üzerine Etkisine İlişkin Çoklu

Regresyon Sonuçları

\begin{tabular}{|c|c|c|c|c|c|}
\hline \multirow[t]{2}{*}{ Model } & \multicolumn{2}{|c|}{$\begin{array}{c}\text { Standardize } \\
\text { Edilmemiş Katsayılar }\end{array}$} & \multirow{2}{*}{$\begin{array}{c}\text { Standardize Edilmiş } \\
\text { Katsayılar } \\
\text { Beta } \\
\end{array}$} & \multirow[t]{2}{*}{$t$} & \multirow[t]{2}{*}{ Sig. } \\
\hline & $\underline{B}$ & Std. Hata & & & \\
\hline (Constant) & 1,320 & 0,214 & & 6,168 & 0,000 \\
\hline İç Özgüven & 0,762 & 0,079 & 0,646 & 9,640 & 0,000 \\
\hline Dış Özgüven & $-0,073$ & 0,070 & $-0,069$ & $-1,036$ & 0,301 \\
\hline
\end{tabular}

Bağımlı Değişken: Kendine Olumlu Bakış

$R=0,595 ; R^{2}=0,354$; Düzeltilmiş $R^{2}=0,350$; Standart Hata $=0,57170$

$F=90,817 ; p=0,000$

Tablo 9'da görüldüğü gibi, iç özgüven düzeyinin kendine olumlu bakış üzerine pozitif yönlü anlamlı bir etkisi $(\beta=0,646)$ mevcuttur $(p<0,05)$. $H_{5 a}$ desteklenmiştir. İç özgüven kendine olumlu bakış düzeyini arttırmaktadır. İç özgüvenin bireyin kendisine ve kendi becerilerine yönelik olması bu sonuçla ilgili olabilir. Dış Özgüven düzeyinin Kendine olumlu bakış üzerine anlamlı bir etkisi yoktur (p>0,05). $H_{5 b}$ reddedilmiştir.

\subsubsection{2. Özgüven Düzeyinin Kendine Olumsuz Bakış Üzerine Etkisi}

Özgüven düzeyi alt boyutlarının kendine olumsuz bakış düzeyi üzerine etkisi çoklu regresyon modeli ile incelenmiştir. Çoklu regresyon testi sonuçları aşağıda Tablo 10 'da verilmiştir. Özgüven düzeyi alt boyutları bağımsız değişken olarak, kendine olumsuz bakış düzeyi bağımlı değişken olarak incelenmiştir.

Tablo 10. Özgüven Düzeyi Alt Boyutlarının Kendine Olumsuz Bakış Üzerine Etkisine Yönelik Çoklu Regresyon Sonuçları

\begin{tabular}{lccccc}
\hline \hline Model & \multicolumn{2}{c}{$\begin{array}{c}\text { Standardize } \\
\text { Edilmemiş Katsayılar }\end{array}$} & $\begin{array}{c}\text { Standardize } \\
\text { Edilmiş Katsayılar }\end{array}$ & $\mathrm{t}$ & Sig. \\
& $\underline{B}$ & $\underline{\text { Std. Hata }}$ & $\underline{\text { Beta }}$ & & \\
\hline (Constant) & 4,600 & 0,353 & & 13,022 & 0,000 \\
İç Özgüven & $-0,512$ & 0,130 & $-0,311$ & $-3,923$ & 0,000 \\
Dış Özgüven & $-0,001$ & 0,116 & $-0,001$ & $-0,012$ & 0,991 \\
\hline
\end{tabular}


Bağımlı Değişken: Kendine Olumsuz Bakış

$R=0,311 ; R^{2}=0,097$; Düzeltilmiş $R^{2}=0,092 ;$ Standart Hata=0,94341

$F=17,776 ; p=0,000$

Tablo 10 'da iç özgüven düzeyinin kendine olumsuz bakış düzeyi üzerine negatif yönlü anlamlı bir etkisi $(\beta=-0,311)$ mevcuttur $(p<0,05)$. $H_{6 a}$ desteklenmiştir. İç özgüven kendine olumsuz bakışı azaltmaktadır. İç özgüvenin kişinin kendi yeterlilik ve başarısıyla ilgili olması bu sonucu ortaya çıkarmış olabilir. Dış Özgüven düzeyinin kendine olumsuz bakış üzerine anlamlı bir etkisi yoktur ( $p>0,05)$. $H_{6 b}$ reddedilmiştir.

\subsection{Değişken Alt Boyutlarına iliş̧kin Ortalamalar}

Aşağıda Tablo 11'de araştırmada kullanılan Mizah Tarzları, Özgüven ve Özsaygı değişkenlerinin alt boyutlarına ilişkin ortalamalar verilmiştir.

Tablo 11. Değişken Alt Boyutlarına ilişskin Ortalamalar

\begin{tabular}{lccc}
\hline \hline & $N$ & Ortalama & Std. Sapma \\
\hline Kendine Yararlı Mizah & 334 & 3,3092 & 0,70959 \\
Sosyal Mizah & 334 & 3,7288 & 0,71743 \\
Kendine Zararlı Mizah & 334 & 2,6964 & 0,63656 \\
Saldırgan Mizah & 334 & 2,3549 & 0,69394 \\
İç Özgüven & 334 & 4,0443 & 0,60100 \\
Dış Özgüven & 334 & 3,7181 & 0,67777 \\
Kendine Olumlu Bakış & 334 & 4,1323 & 0,70933 \\
Kendine Olumsuz Bakış & 334 & 2,5257 & 0,98980 \\
\hline
\end{tabular}

Tablo 11'de görüldüğü gibi mizah tarzları ölçeği alt boyutları içinde sosyal mizah boyutu en yüksek ortalamaya $(3,7288)$ sahip iken, saldırgan mizah boyutu en düşük ortalamaya $(2,3549)$ sahiptir. Özgüven ölçeği alt boyutlarından iç özgüven boyutu ortalaması $(4,0443)$, dış özgüven boyutu ortalamasından $(3,7181)$ daha yüksektir. Özsaygı ölçeği alt boyutlarından kendine olumlu bakış boyutu ortalaması $(4,1323)$, kendine olumsuz bakış boyutu ortalamasından $(2,5257)$ daha yüksektir. 


\section{Tartışma ve Sonuç}

Öğrencilerin kendine yararlı mizah ve sosyal mizah algılarının artması hem iç özgüven düzeylerini hem de dış özgüven düzeylerini arttırmaktadır. Bu sonuçlar kendine yararlı mizah ve sosyal mizahın olumlu mizah tarzları olmasıyla ilgili olabilir. Ayrıca kendine yararlı mizahın kişinin mizahi yaklaşımına dayanması ve sosyal mizahın kişilerarası iletişimle ilgili olması bu sonuçları ortaya çıkarmış olabilir. Kendine yararlı mizahın sosyal mizaha göre hem iç özgüveni hem de dış özgüveni daha çok arttırdığı ifade edilebilir. Bu açıdan kendine yararlı mizahın özgüven üzerine etkisinin daha çok olduğu ifade edilebilir. Sonuç olarak kendine yararlı mizah ve sosyal mizah düzeyinin özgüveni arttıran önemli değişkenler olduğu ortaya çıkmıştır.

Öğrencilerin kendine yararlı mizah ve sosyal mizah algılarının artması kendine olumlu bakış düzeylerini yükseltmektedir. Kendine yararlı mizahın olumlu davranışlarla ilgili olması ve sosyal mizahın iletişimi geliştirici bir anlayışı yansıtması bu sonuçla ilgili olabilir. Kendine yararlı mizahın sosyal mizaha göre kendine olumlu bakış düzeyi üzerine etkisinin daha çok olduğu söylenebilir. Bu açıdan kendine yararlı mizah düzeyinin kişiler için önemi ortaya çıkmaktadır.

Öğrencilerin sosyal mizah algılarının artması kendine olumsuz bakış düzeylerini azaltmaktadır. Sosyal mizahın olumlu duygu ve düşüncelere dayanan bir mizah tarzı olması bu sonuçla ilgili olabilir. Öğrencilerin kendine zararlı mizah algılarının yükselmesi kendine olumsuz bakış düzeylerini arttırmaktadır. Kendine zararlı mizah tarzının olumsuz bir yaklaşım içermesi bu sonuçla ilişkili olabilir.

Vaughan, Zeigler-Hill ve Arnau (2014) üniversite öğrencilerinin Mizah tarzları ve özsaygıları düzeyleri arasındaki ilişkiyi incelemişlerdir. Vaughan, Zeigler-Hill ve Arnau (2014) yüksek özsaygıya sahip kişilerin yüksek düzeyde katılımcı mizah tarzı, düşük düzeyde saldırgan mizah tarzı ve düşük düzeyde kendini yıkıcı mizah tarzına sahip olduklarını belirtmişlerdir. Hiranandani ve Yue (2014) üniversite öğrencilerine yönelik gerçekleştirdikleri çalışmalarında düşük özsaygıya sahip kişilerin yüksek düzeyde kendini yıkıcı mizah tarzlarına sahip olduklarını ortaya koymuşlardır. Hiranandani ve Yue (2014) öğrencilerin en fazla katılımc ve kendini geliştirici mizaha sahip olduklarını ifade etmişlerdir. Hiranandani ve Yue (2014) özsaygının katılımc mizah ve kendini geliştirici mizah ile pozitif yönlü ilişkiye sahip olduğunu belirtmişlerdir.

Traş, Arslan ve Mentiş Taş (2011) eğitim fakültesi öğrencilerine yönelik mizah tarzları, problem çözme ve benlik saygısı üzerine bir çalışma gerçekleştirmişlerdir. Traş, Arslan ve Mentiş Taş (2011), özsaygı ile katılımcı mizah ve kendini geliştirici mizah arasında pozitif bir ilişki olduğunu belirlemişlerdir. Traş, Arslan ve Mentiş Taş (2011) özsaygı ile saldırgan mizah ve kendini yıkıı mizah arasında negatif yönlü bir ilişki olduğunu ifade etmişlerdir. Zeigler-Hill ve Besser (2011) üniversite öğrencileri üzerine gerçekleştirdikleri araştırmalarında özsaygı düzeyi ile katılımcı mizah ve kendini geliştirici mizah arasında pozitif yönlü bir korelasyon olduğunu ortaya koymuşlardır. Zeigler-Hill ve Besser (2011) özsaygı seviyesi ile saldırgan mizah ve kendini yıkıcı mizah arasında negatif yönlü bir korelasyon olduğunu ifade etmişlerdir. 
Zhao, Kong ve Wang (2012), kolej öğrencilerine yönelik araştırmalarında kendini geliştirici mizah düzeyinin özsaygı üzerine pozitif yönlü anlamlı bir etkisinin olduğunu belirtmişlerdir. Zhao, Kong ve Wang (2012) araştırmalarında özsaygının kendini geliştirici mizah ve katılımcı mizah ile pozitif yönlü, kendini yıkıcı mizah ve saldırgan mizah ile negatif yönlü bir korelasyona sahip olduğunu belirtmişlerdir. Zhao, Wang ve Kong (2014), üniversite öğrencilerine yönelik araştırmalarında katılımcı mizah ve kendini geliştirici mizahın özsaygı üzerine pozitif yönlü bir etkisinin olduğunu belirtmişlerdir. Zhao, Wang ve Kong (2014), özsaygının katılımcı mizah ve kendini geliştirici mizah ile pozitif, saldırgan mizah ve kendini yıkıcı mizah ile negatif ilişkisi olduğunu ortaya koymuşlardır.

Araştırmada da benzer sonuçlar elde edilmiştir. Araştırmada kendine yararlı mizahın ve sosyal mizahın özsaygının pozitif alt boyutu olan kendine olumlu bakış seviyesini arttırdı̆̆ı görülmüştür. Araştırmada sosyal mizahın kendine olumlu bakış düzeyini arttırdığı, kendine olumsuz bakış düzeyini azalttı̆̆ı ifade edilmiştir. Ayrıca araştırmada kendine zararlı mizah düzeyinin özsaygının negatif alt boyutu olan kendine olumsuz bakışı yükselttiği görülmüştür. Araştırmada da mizah tarzları içinde sosyal mizah ve kendine yararlı mizah tarzlarının ortalamalarının en yüksek değerde olduğu görülmüştür. Bu kapsamda öğrencilerin mizah tarzları içinde en fazla sosyal mizaha ve daha sonra kendine yararlı mizaha sahip oldukları ifade edilebilir.

İç özgüven kendine olumlu bakış düzeyini arttıırken, kendine olumsuz bakış seviyesini azaltmaktadır. Öğrencilerin iç özgüven algılarının artması kendine olumlu bakış düzeylerini arttırırken, kendine olumsuz bakış düzeylerini azaltmaktadır. Bu açıdan iç özgüvenin özsaygıyı arttıran önemli bir faktör olduğu ifade edilebilir. İç özgüvenin bireyin kendisi ve kendi nitelikleriyle ilgili olması bu sonuçları ortaya çıkarmış olabilir.

\section{Kaynaklar}

Akın, A. (2007). “Öz-güven Ölçeği'nin Geliştirilmesi ve Psikometrik Özellikleri”, Abant lizzet Baysal Üniversitesi Eğitim Fakültesi Dergisi, Cilt 7, Sayı 2, 167-176.

Akın, A. (2015). "Psikolojide Kullanılan Güncel Ölçme Araçları", 2. Baskı, Cilt 2, Nobel Akademik Yayıncılık, Ankara.

Akkuş Çutuk, Z. (2017). “5. Sınıf Öğrencilerinin Sosyal Becerilerinin Özsaygı ve Denetim Odağı İle ilişkisi”, Abant İzzet Baysal Üniversitesi Eğitim Fakültesi Dergisi, 17(2), 505-525.

Alpar, R. (2011). Uygulamalı Çok Değişkenli İstatistiksel Yöntemler, 3.Baskı, Detay Yayıncılık, Ankara.

Aslan, H. ve Çeçen, A. R. (2007). “Ortaöğretim Kurumlarında Görev Yapan Öğretmenlerin Cinsiyetlerine ve Öğrenilmiş Güçlülük Düzeylerine Göre Mizah Tarzlarının İncelenmesi”, Ç.Ü. Sosyal Bilimler Enstitüsü Dergisi, Cilt 16, Sayı 2, 1-14. 
Beck, A.T. ve Emery, G. (2015). Anksiyete Bozuklukları ve Fobiler, (Çev.:Veysel Öztürk), 3. Baskı, Litera Yayıncılık, İstanbul.

Çokluk, Ö., Şekercioğlu, G. ve Büyüköztürk, Ş. (2012). Sosyal Bilimler Için Çok Değişkenli Istatistik SPSS ve LISREL Uygulamaları, 2.Baskı, Pegem Akademi, Ankara.

Çuhadaroğlu, F. (1986). “Adolesanlarda Benlik Saygısı”, Basılmamış Uzmanlık Tezi, Hacettepe Üniversitesi Tıp Fakültesi Psikiyatri Anabilim Dalı, Ankara.

Erözkan, A. (2009). “Üniversite Öğrencilerinin Kişiler Arası Ilişki Tarzları ve Mizah Tarzları”, Dokuz Eylül Üniversitesi Buca Eğitim Fakültesi Dergisi, 26, 56-66.

Galloway, G. (2010). "Individual Differences in Personal Humor Styles: Identification of Prominent Patterns and their Associates", Personality and Individual Differences, 48, 563-567.

Hiranandani, N.A. ve Yue, X.D. (2014). "Humour Styles, Gelotophobia and Self-esteem among Chinese and Indian University Students", Asian Journal of Social Psychology, 17, 319-324.

Hogg, M.A. ve Vaughan, G.M. (2007). Sosyal Psikoloji, (Çev.=ibrahim Yıldız ve Aydın Gelmez), 1. Baskı, Ütopya Yayınevi, Ankara.

Karacan Özdemir, N. (2016). “Deneysel Bir Çalışma: Bibliyopsikolojik Danışmaya Dayalı Özgüven Geliştirme Programının 6. Sınıf Öğrencilerinin Özgüven Düzeylerine Etkisi”, illköğretim Online, 15(1), 136-147.

Karadoğan Doruk, S.E. (2005). "ilişkilerde Başarının Anahtarı: Özgüven”, İstanbul Üniversitesi iletişim Fakültesi Dergisi, Sayı 23, 259-267.

Maclellan, E. (2014). "How might Teachers Enable Learner Self-confidence? A Review Study", Educational Review, Vol.66, No.1, 59-74.

Maroiu, C., Maricutoiu, L.P. ve Sava, F.A. (2016). "Explicit Self-esteem and Contingencies of Selfworth: The Moderating Role of Implicit Self-esteem", Personality and Individual Differences, 99, 235-241.

Martin, R.A., Puhlik-Doris, P., Larsen, G., Gray, J. ve Weir, K. (2003). "Individual Differences in Uses of Humor and their Relation to Psychological Well-being: Development of the Humor Styles Questionnaire", Journal of Research in Personality, 37(1), 48-75.

Martin, R.A., Lastuk, J.M., Jeffery, J., Vernon, P.A. ve Veselka, L. (2012). "Relationships between the Dark Triad and Humor Styles: A Replication and Extension", Personality and Individual Differences, 52, 178-182.

Okyay, B. (2012). "Yönetici ve Çalışanların Özgüven Düzeyleri ve Kişisel Gelişim İnisiyatifi Alma Becerilerinin Karşılaştıııması”, Basılmamış Yüksek Lisans Tezi, Maltepe Üniversitesi Sosyal Bilimler Enstitüsü Psikoloji Anabilim Dalı, İstanbul. 
Özbay, Y., Palancı, M., Kandemir, M. ve Çakır, O. (2012). “Üniversite Öğrencilerinin Öznel İyi Oluşlarının Duygusal Düzenleme, Mizah, Sosyal Öz-yeterlik ve Başaçıkma Davranışları ile Yordanması", Türk Eğitim Bilimleri Dergisi, 10(2), 325-345.

Reisoğlu, S. ve Yazıcı, H. (2017). “Üniversite Öğrencilerinin Öznel İyi Oluşlarını Yordamada Beş Faktör Kişilik Özellikleri, Mizah Tarzları ve Duygusal Zekanın Rolü", Journal of History Culture and Art Research, 6(4), September, 888-912.

Reisoğlu, İ., Gedik, N. ve Göktaş, Y. (2013). “Öğretmen Adaylarının Özsaygı ve Duygusal Zekâ Düzeylerinin Problemli İnternet Kullanımıyla Ilişkisi”, Eğitim ve Bilim, Cilt 38, Sayı 170, 150-165.

Rosenberg, M. (1965). "Society and the Adolescent Self-Image”, New Jersey: Princeton Universtiy Press.

Traş, Z., Arslan, C. ve Mentiş Taş, A. (2011). “Öğretmen Adaylarında Mizah Tarzları, Problem Çözme ve Benlik Saygısının İncelenmesi”, Uluslararası Insan Bilimleri Dergisi, Cilt 8, Sayı 2, 716 732.

Vaughan, J., Zeigler-Hill, V. ve Arnau, R.C. (2014). "Self-Esteem Instability and Humor Styles: Does the Stability of Self-Esteem Influence How People Use Humor?", The Journal of Social Psychology, 154, 299-310.

Veselka, L., Schermer, J.A., Martin, R.A. ve Vernon, P.A. (2010). "Relations between Humor Styles and the Dark Triad Traits of Personality", Personality and Individual Differences, 48, 772-774.

Yerlikaya, E.E. (2003). "Mizah Tarzları Ölçeği'nin (The Humor Styles Questionnaire) Uyarlama Çalışması”, Basılmamış Yüksek Lisans Tezi, Çukurova Üniversitesi Sosyal Bilimler Enstitüsü Eğitim Bilimleri Anabilim Dalı, Adana.

Zeigler-Hill, V. ve Besser, A. (2011). "Humor Style Mediates the Association between Pathological Narcissism and Self-esteem", Personality and Individual Differences, 50, 1196-1201.

Zhao, J., Kong, F. ve Wang, Y. (2012). "Self-esteem and Humor Style as Mediators of the Effects of Shyness on Loneliness among Chinese College Students", Personality and Individual Differences, 52, 686-690.

Zhao, J., Wang, Y. ve Kong, F. (2014). "Exploring the Mediation Effect of Social Support and Selfesteem on the Relationship between Humor Style and Life Satisfaction in Chinese College Students", Personality and Individual Differences, 64, 126-130. 